\title{
Rektors roll som pedagogisk ledare i IKT-baserat skolutvecklingsprojekt
}

\begin{abstract}
The principal of a Swedish school is among other duties the responsibility for the pedagogical development of the school. This article analyses how the principals act as pedagogical leaders in a collaborative ICT project (Information and Communication Technology). The analysis is based on a case study of an EU funded Nordic school development project where the goal was to develop cross-boarder educational models between the national education systems in the three participating countries Sweden, Denmark and Norway. The project was based on virtual communication between the schools using digital technology. The study investigated how the teachers from two schools involved in the project experienced the leadership of the principals in ICT related matters. The teachers were interviewed to find out how they perceived the support they had received from the principals on pedagogical issues, technical equipment and ICT competence. The interviews were analysed using Dexter's three basic features, "setting direction", "developing people" and "making the organisation work". Two kinds of leadership were found. The first resembled a team-based leadership, or what is known as distributed leadership, in which the principal worked closely with teachers and ICT managers. The second resembled more a formal leadership approach in which principals had a positive attitude towards ICT development but conventional organisational roles were retained. In development projects where ICT will be integrated into teaching requires different types of skills and experience, and hence also between different professional competencies. The project as a working method can in the study be seen as a model for developing distributed leadership.
\end{abstract}

Keywords: computing, distributed leadership, ICT leadership, team-based school leadership, school development project.

\section{Sammandrag}

I artikeln undersöks hur rektor i sin roll som pedagogisk ledare agerar som stöd åt lärarna i samband med ett IKT-baserat skolutvecklingsprojekt (Information och kommunikationsteknik). Studien bygger på en fallstudie i ett EU-finansierat nordiskt skolprojekt där målet var att utveckla gränsöverskridande pedagogiska modeller för undervisning mellan klasser i de tre deltagande länderna Sverige, 
Danmark och Norge. Projektet byggde på virtuell kommunikation mellan skolorna med hjälp av digital teknik. Studien undersökte hur lärare från två skolor som deltog i projektet upplevde sina rektorer i IKT-relaterade frågor. En kvalitativ metod användes där lärarna intervjuades för att ta reda på hur de upplevde det stöd de fått från rektorerna gällande pedagogiska frågor, teknisk utrustning och IKT-kompetens. Som analysmodell användes tre funktioner som enligt Dexter (2008) anses gynna ett IKT-ledarskap, nämligen "att formulera mål och visioner", "att utveckla personalen" och "att se till att organisationen fungerar". Resultatet visar på två typer av ledarskap. Det ena hade likheter med ett kollektivt ledarskap eller ett så kallat distribuerat ledarskap, där rektor arbetade nära lärare och IKT-pedagoger. Det andra liknade mer ett traditionellt, formellt ledarskap där rektorerna hade en positiv inställning till IKT-utveckling, men där de olika yrkesrollerna arbetade var för sig. I ett utvecklingsprojekt där IKT ska integreras i undervisningen krävs olika typer av kunskaper och erfarenheter och därmed behövs samverkan mellan olika yrkeskompetenser. Projekt som arbetsform kan därför ses som en möjlighet för att utveckla ett distribuerat ledarskap.

Nyckelord: digital användning, distribuerat ledarskap, IKT-ledarskap, kollektivt ledarskap, skolutvecklingsprojekt.

\section{Inledning}

Rektors roll som pedagogisk ledare har blivit allt viktigare för skolans utveckling (Hallerström, 2006: Berg 2011; Höög \& Johansson, 2011; Larsson \& Löwstedt, 2014). I det pedagogiska ledarskapet ingår ansvar för elevers lärande genom att organisera förutsättningar för undervisning och arbetsklimat. Den pedagogiska rollen innebär att stimulera lärare i sin professionella utveckling så att eleverna får den undervisning som ger dem möjlighet att nå målen enligt den nationella läroplanen (Skolverket, 2011). Detta medför att rektor är ansvarig för pedagogisk utveckling, uppföljning och utvärdering av resultat samt att skolan tillhandahåller läromedel och teknisk utrustning. Med detta ansvar följer att rektor behöver ha ett nära samarbete med lärarna så att rektor blir till stöd för undervisning och skolutveckling. Emellertid visar Skolinspektionens tillsynsrapporter på en rad brister i rektorers pedagogiska ledarskap. (Skolinspektionen, 2012a; 2014). När det gäller användning av IKT (informations- och kommunikationsteknik) i undervisningen visar rapporterna att skolledningen inte styr den på ett aktivt sätt. Många skolor saknar övergripande strategier för användning av IKT i det pedagogiska arbetet. Vidare framhålls att lärarnas behov av kompetensutveckling för att använda IKTverktyg i det pedagogiska arbetet inte har tillgodosetts (Skolinspektionen, 2012b; Hylén, 2013). Följaktligen föreligger behov av kompetensutveckling för såväl rektorer som lärare inom IKT. En kompetens som handlar om pedagogiskt 
kunnande i kombination med teknik och ämnesinnehåll (Harris m. fl., 2009; Tallvid, 2015). Frågan är på vilket sätt lärare anser att rektor som pedagogisk ledare främjar en sådan utveckling. Mycket har forskats kring ledarskap i skolan men mera sällsynt är forskning om lärares uppfattningar om rektors agerande som pedagogiskt stöd till lärarna för integrering av IKT i undervisningen.

Föreliggande artikel fokuserar på lärares uppfattningar om rektor som pedagogisk ledare i skolor som deltagit i ett skolutvecklingsprojekt med fokus på IKT och virtuell kommunikation, i denna artikel kallad NGU-projektet (Nordisk Gränsöverskridande Undervisning). Artikeln belyser en fallstudie där rektors ledarskap från två skolor undersöks utifrån ett lärarperspektiv. I NGUprojektet var rektor en nyckelfigur när det gällde att ge förutsättningar för deltagande lärare och klasser. Exempelvis beslutade rektor om hur mycket tid som lärarna skulle tilldelas i projektet för att planera lektioner och kommunicera med lärare från andra skolor. Det beslutades på ledningsnivå om teknisk utrustning och infrastruktur samt att allt detta fungerade i projektet. Förutom uppgifter av rationell och teknisk natur är rektors personliga engagemang av betydelse för ett projekt. Ett skolprojekt utan personligt stöd eller engagemang från rektors sida har lägre chans att lyckas (Stedøy, 2006; Petersen, 2010, 2012a, 2013). Syftet i denna studie var att undersöka hur lärarna i NGU-projektet upplevde rektor som pedagogisk ledare och stöd när det gällde IKT-användning i undervisningen och att utifrån lärarnas uppfattningar förstå vilken typ av ledarskap som främjar IKT-utveckling i undervisningen. I studien jämförs och diskuteras lärarnas uppfattningar om sina respektive rektorers ledarskap. Däremot ingår det inte $\mathrm{i}$ studien att undersöka och värdera det gränsöverskridande arbetet $\mathrm{i}$ undervisningen mellan klasser i de nordiska länderna och inte heller elevers studieresultat.

Frågeställningar i studien:

1. Vilket stöd upplevde lärarna att de erhållit från sina rektorer i samband med IKT-användning i NGU-projektet när det gällde kompetensutveckling, teknik och IKT-utveckling på skolan?

2. Vad karaktäriserar rektorernas pedagogiska ledarskap inom ramen för NGU-projektet, utifrån lärarnas uppfattningar?

\section{Rektors ledarskap viktig för skolutveckling}

I samband med övergången från regel- till mål- och resultatstyrning inom skolan i början av 1990-talet, fick rektor en ny roll som pedagogisk ledare för sin skolenhet. I den tidigare rollen låg betoningen på ett förvaltande ledarskap där det handlade om att vara uttolkare av de statliga reglerna och få verksamheten att fungera efter de bestämmelser och anvisningar som gällde. Rektor och lärare hade olika uppgifter, rektor ansvarade för den administrativa delen och lärarna såg undervisningen som sin uppgift. Den resultatstyrda skolan kräver ett annat ledarskap, ett utvecklande ledarskap, som strävar efter att utveckla en skolkultur 
som kännetecknas av samarbete och professionalism (Ekholm m.fl., 2000; Skolverket, 2011; Skolinspektionen, 2012). Dock lever den gamla ordningen kvar på sina håll genom det Berg (2011) kallar det osynliga kontraktet, ett handlingsmönster som behöver förändras då ledarskapet handlar om en ömsesidig process mellan rektor och lärare och den samverkan som skapas däremellan.

Ledarskapet framhålls som avgörande för utveckling av innovativa skolkulturer (Fullan, 2007) och här utgör IKT-användning inget undantag (Owstone, 2003). Björkman (2011, s. 140) har studerat rektorer i olika skolor utifrån skolförbättringsprocesser. Han visar på två typer av ledarskap: ett lyckat ledarskap, "involverande ledarskap", och ett mindre lyckat, "separerande ledarskap". Det involverande ledarskapet innebär att rektor har en idé om att alla kan bidra till skolutveckling. Det kännetecknas av en öppenhet om vad som pågår på skolan samt en tolerans för olika åsikter i diskussioner om utbildningsfrågor. Rektor var ofta närvarande i det dagliga klassrumsarbetet, aktiv i de regelbundna pedagogiska mötena och gav lärarna regelbunden feedback. I det separerande ledarskapet höll sig rektor mer till sin formella position som verksamhetsansvarig medan lärarna var ansvariga för undervisningen i sina respektive ämnen och för den pedagogiska utvecklingen. Rektor deltog i arbetsplatsmöten, men inte i de pedagogiska mötena som lärarna själva organiserade. Detta ledde till att lärarna hade frihet inom sina ämnen, men saknade en gemensam hållning för att utveckla undervisningen på skolan.

\section{Distribuerat ledarskap för IKT-integrering}

Ökad IKT-användning innebär ett nytt sätt att se på undervisning som ställer nya krav på lärare, skolledning och organisering av verksamheten (Petersen \& Bunting, 2012; Lantz-Andersson \& Säljö, 2014; Lundgren, 2014). Skolor som bedriver IKT-utveckling med en teambaserad organisation har varit mer framgångsrika än skolor som kännetecknas av formella organisationsstrukturer eller självständiga individer. Skolor med den formella strukturen har inte på samma sätt kunnat samordna och sprida lärarnas erfarenhet och kompetens (Larsson, 2004; Erstad, 2011; Larsson \& Löwstedt, 2014). Kritiska faktorer som avgör om lärare arbetar med IKT eller inte visar sig vara rektors stöd till lärare i pedagogisk utveckling, teknisk utrustning och support (Law, 2008; Ottestad, 2013;). Här spelar tid för planering och utveckling av undervisning en viktig roll (Schibeci et al., 2008). IKT-integration är också beroende av lärarnas inställning och pedagogiska övertygelse; övertygelse om att IKT kan göra undervisningen effektivare (Bryderup \& Kowalski, 2002; Ertmer \& Ottenbreit-Leftwich, 2010).

Dexter (2008) och Bennett (2008) framhåller vikten av ett IKT-ledarskap där en grupp individer med olika kompetenser delar kunskaper och erfarenheter med varandra så kallat "distributed leadership", översatt till svenska distribuerat ledarskap - i texten förkortat D.L. Under de senaste decennierna har D.L. vuxit fram som ett samlingsbegrepp för olika typer av delat- eller samverkande 
ledarskap, shared- or collaborative leadership, även kallat demokratiskt-, teambaserat- och deltagande ledarskap. Även om dessa är olika benämningar på D.L. kan de ej betraktas som synonymer, då olika faktorer och betydelser lyfts fram i de olika sammanhangen (Harris m.fl., 2007, sid. 338; Spillane, 2005; Leithwood m.fl., 2007). I ett distribuerat perspektiv är det ledarskapets praktik som står i centrum, där praktiken ses som en produkt av interaktion mellan rektor, pedagoger, annan personal och deras respektive kompetenser och erfarenheter. Skolans IKT-ledarskap kan ur ett sådant perspektiv bäst förstås i termer av de frågor och utmaningar som måste lösas och mindre i termer av varje individs formella yrkesroll (Dexter, 2008). Den mångfacetterade betydelsen av D.L. har gjort det svårt att empiriskt få fram tillförlitliga forskningsresultat om hur det exempelvis påverkar elevers studieresultat (Leithwood m. fl., 2006). Dock finns det forskning om hur D.L. påverkar organisationens verksamhet. Leithwood m. fl. (2008) har funnit två förutsättningar som viktiga för att skapa ett effektivt D.L. Dels bör det samverkande teamet bestå av individer som har kunskaper eller expertis om de områden de har att utveckla. Dels bör det samverkande teamet koordineras och drivas på ett planerat sätt.

Genom betoningen på ledarskapets kollektiva karaktär bygger D.L. på vad som anses utgöra grunden för ett framgångsrikt ledarskap, nämligen att stödja de anställda i att utveckla sin yrkesskicklighet, vad gäller såväl kunskaper och färdigheter som värderingar och motivation men också förhållanden på arbetsplatsen för att utföra sitt arbete (Leithwood m. fl., 2006; Leithwood m. fl., 2007; Leithwood m. fl., 2008; Hallinger \& Heck, 2010). Ett D.L ur ett IKTperspektiv behöver skolledaren både ha kunskaper inom IKT-området och kunna organisera skolverksamheten (Dexter, 2008). Författaren framhåller tre funktioner som bör prägla skolans ledarskap för att utveckla digital användning i undervisningen: 1. "Setting direction", att formulera visioner och mål för verksamheten. 2. "Developing people", att stödja och utveckla lärarna professionellt. 3. "Making the organisation work", att organisera verksamheten så att den fungerar (s. 543). Följaktligen handlar det om att formulera mål och visioner för hur skolan ur ett pedagogiskt perspektiv förhåller sig till IKT i undervisningen. Utifrån en sådan målsättning behöver personalen utvecklas, erbjudas kompetens för att skapa lärande i en IKT-integrerad miljö. Detta innebär kompetenshöjande utbildning inom både tekniskt och pedagogiskt område, kontinuerligt stöd och stimulera till kommunikation mellan pedagoger och mellan rektor och pedagoger. Den tredje funktionen gäller organisering av skolans verksamhet, tillhandahållande av resurser, teknik, infrastruktur och inte minst skapa tid och rum för pedagogiska möten. De tre funktionerna används i studien som analysram i diskussionen om lärarnas uppfattningar om rektors IKT-ledarskap i NGU-projektet. 


\section{Skolprojektet NGU}

Syftet med föreliggande fallstudie var att undersöka hur lärarna upplevde sina respektive rektorers pedagogiska ledarskap i skolprojektet NGU när det gällde IKT-användning i undervisningen. Studien syftade också till att förstå vilken typ av ledarskap som främjar IKT-utveckling i undervisningen. Med fallstudie menas en forskningsstrategi som fokuserar på att förstå dynamiken hos några enstaka fall (Eisenhardt, 1989). I detta fall lärares uppfattningar om sina respektive rektorers pedagogiska ledarskap från två skolor, som i studien kallas Apelskolan och Pilskolan. NGU-projektet byggde på virtuell kommunikation mellan klasser i årskurserna 5-9 från Sverige, Norge och Danmark. NGU var ett EU-finansierat treårigt nordiskt skolutvecklingsprojekt (år 2011-2014). I Sverige deltog från början sex skolor i projektet, fyra i Norge och tre i Danmark. Projektet startade med 16 klassamarbeten mellan två eller tre länders klasser. Skolorna deltog i ämnena matematik, naturkunskap, historia/samhällskunskap och modersmål. Målsättningen i projektet var att utveckla gränsöverskridande undervisningsmodeller med hjälp av digitala verktyg och sprida dessa modeller inom respektive skola. Det senare kunde te sig problematiskt i föreliggande studie, då de två skolorna hade relativt få deltagande klasser och lärare. I sådana fall föreliggger risk för att skapa "öar" och inte sprida kunskaper från projektet till resten av skolan (Grensjö, 2002).

Ett antal forskare följde och studerade projektet utifrån en aktionsinriktad forskningsansats, en metodansats som bygger på forskning i praktiken i stället för i teorin (Friedman, 2001; Denscombe, 2009). Forskarens roll var i detta fall att diskutera, förtydliga och problematisera förhållanden som ansågs relevanta att utveckla i projektet tillsammans med praktikerna. Forskare med olika kompetenser var inblandade i projektet; ur ett ämnesperspektiv, ur ett IKTperspektiv och ur ett skolledarperspektiv. Undertecknad författare har deltagit som forskare tillsammans med skolledarna.

Att driva ett skolprojekt skiljer sig från det dagliga arbetet i skolan. Ett projekt brukar beskrivas som en tillfällig verksamhet, som utförs med tydligt avgränsade resurser i syfte att uppnå ett bestämt mål (Hallin \& Karrbom Gustavsson, 2012). Inom ramen för målsättningen hade lärarna i den nordiska samverkan ett stort spelrum när det gällde att planera och utveckla digitala undervisningsmodeller inom sina respektive ämnen.

I studien intervjuades lärare från två av de svenska skolorna efter att ha deltagit i projektet under 1,5 år. De två skolorna valdes ut för studien av två skäl. I båda skolorna fungerade det gränsöverskridande klassamarbetet tämligen väl, även om det initialt var en del svårigheter. Klasserna hade fullföljt de planerade samarbetena, det fanns ett engagemang hos både lärare och elever och de ansåg att de hade lärt sig en hel del av projektet. Det andra skälet byggde på olikhet, då de två skolorna skiljde sig åt vad gällde elevernas etniska och socioekonomiska bakgrund. Även om denna skillnad inte utgjorde någon huvudfråga i studien kunde det vara intressant att se hur lärarnas syn på sina 
rektorers ledarskap skiljde sig åt. Lärare behöver anpassa sin undervisning efter elevunderlaget och på samma vis antas rektor behöva anpassa sitt ledarskap. Apelskolan var en F-9 skola (förskola till och med årskurs 9). Skolan var ganska ny, mångkulturell där 85-90 \% av eleverna hade annat modersmål än svenska. Skolan låg i utkanten av en medelstor svensk kommun, i ett socialt och ekonomiskt utsatt område. Elevernas prestationer på de nationella proven visade förhållandevis låga resultat (Skolverket, 2013). Apelskolan hade två kvinnliga rektorer; en av dem hade flera års erfarenhet som rektor på annan skola medan den andra endast hade något års erfarenhet på Apelskolan. Skolan deltog i NGUprojektet med en 6:e klass i ämnet matematik och klassen hade två kvinnliga lärare, 34 år respektive 54 år och de var utbildade 1-7 lärare med behörighet i matematik. Till skillnad från Apelskolan låg Pilskolan i en förort till en större stad med elever från en högre socioekonomisk bakgrund. Skolan var relativt sett gammal och de flesta eleverna hade svenska som sitt modersmål. Pilskolan undervisade årskurs 7-9 och hade också två kvinnliga rektorer, som båda tillträtt sina tjänster efter första året i NGU. En av rektorerna hade tidigare varit IKTsamordnare på skolan och den andra hade ett förflutet som rektor i en intill liggande skola. Pilskolan deltog i NGU-projektet med en 8:e klass i ämnet modersmål med en kvinnlig lärare 34 år och en 9:e klass i ämnet naturkunskap med en annan kvinnlig lärare 49 år. Båda lärarna hade ämneslärarutbildning $\mathrm{i}$ sina respektive ämnen. Både Apel- och Pilskolan hade försett eleverna med bärbara datorer.

\section{Forskningsdesign och metod}

Studiens forskningsdesign och metod bygger på ett socialkonstruktivistiskt synsätt där lärande och utveckling sker i den sociala praktiken, genom individens delaktighet och där symboliska redskap som språkbruk och artefakter av olika slag blir avgörande för hur vi förstår, tänker och uppfattar världen (Dysthe, 2001; Hundeide, 2003; Säljö, 2015). Denna syn ligger också i linje med det Voogt (2008) menar kännetecknar en utvecklande pedagogik i IKT-baserad undervisning, nämligen att den studerande inte bara är konsument av kunskap utan också är producent och är med och utvecklar ny kunskap.

En kvalitativ metod användes för att få en förståelse för hur rektors pedagogiska ledarskap upplevdes ur lärarnas synvinkel (Kvale, 2008). Intervjuer genomfördes vid ett tillfälle med de deltagande lärarna i projektet från de två skolorna i mitten av den fjärde terminen av projektets totalt sex terminer. Intervjuerna genomfördes parvis på varje skola under cirka 50-60 minuter och svaren spelades in på en ljudfil. De förberedda frågorna var utgångspunkten för intervjuerna men lärarna uppmuntrades också att tala fritt. Som vid all forskning baserad på intervjuer finns det en potentiell fara att respondenterna svarar vad de tror förväntas av dem eller att svaren vinklas av andra skäl. I det här fallet kan en potentiell partiskhet inte ignoreras, särskilt som författaren hade följt projektet sedan starten, även om hon inte hade haft någon direkt tidigare kontakt 
med lärarna. Det var dock viktigt att vara medveten om denna roll vid genomförandet av intervjuerna och det krävdes en noggrann tolkning av svaren samt en medvetenhet om den egna förförståelsen av projektet och dess utveckling (Fejes \& Thornberg, 2009). Forskarens kunskaper om projektet och att hon var bekant med rektorerna $\mathrm{i}$ fråga kan samtidigt ha bidragit till en igenkänning och därmed en mera trovärdig tolkning av respondenternas svar. Vissa omständigheter i projektet hade redan diskuterats på de återkommande rektorsmötena, där undertecknad varit ordförande. Silverman (2006) påpekar forskarens ansvar för de personer som deltar i studien med avseende på deras anonymitet. De intervjuade lärarna informerades om de etiska aspekterna som deltagandet i studien innebar. I detta fall förväntades lärarna prata om sina överordnanden, vilket dessutom kunde vara känsligt och därför riskera att snedvrida svaren. När lärarna tillfrågades om att delta i intervjun var samtliga positiva och visade inte någon som helst tvekan. Även rektorerna informerades om studien och hade inga invändningar till dess genomförande.

Intervjufrågornas innehåll formulerades utifrån de förväntningar på rektor som pedagogisk ledare inom ramen för NGU. Frågorna handlade om hur lärarna upplevt stödet från sina rektorer ur såväl pedagogisk som organisatorisk synvinkel. En första punkt handlade om varför NGU-projektet skulle genomföras, vilken vision som stod i centrum. Vidare handlade frågorna om vad det pedagogiska och organisatoriska stödet bestod av, hur det såg ut och vad som saknades.

1. Har rektor formulerat någon vision för användning av IKT i undervisningen i NGU-projektet?

2. Vilket stöd upplever du att du får av rektor vid IKT-användning i NGUprojektet?

3. Vilket stöd skulle du ha velat ha?

4. Hur stödjer/leder rektor din kompetensutveckling för att integrera IKT i undervisningen i samband med NGU-projektet?

5. Hur stimulerar rektor samarbete mellan lärarna för att utveckla IKTanvändning i undervisningen?

6. Rektor är ytterst ansvarig för skolan och har därför många olika uppgifter att hantera. Det pedagogiska ledarskapet är en av dem. Beskriv hur du upplever rektors pedagogiska ledarskap.

Lärarintervjuerna transkriberades och kategoriserades i förhållande till vad och hur lärarna upplevt att deras rektorer engagerat sig för att utveckla IKTanvändning i undervisningen med särskilt fokus på NGU-projektet. Lärarna på respektive skola var inte på någon punkt oeniga i sina svar. Redovisningen nedan gäller för lärarparens uppfattningar om rektors ledarskap för Apelskolan (L.A.) respektive Pilskolan (L.P.). 


\section{Resultat: Två typer av ledarskap}

Resultatet illustrerar två typer av ledarskap, där Apelskolans lärare beskriver hur rektorerna arbetar nära lärarna och hur de aktivt deltar i IKT-utvecklingen. I Pilskolans lärarbeskrivning deltar däremot inte rektorerna i undervisning eller i IKT-utveckling, men där förväntar sig heller inte lärarna någon större delaktighet från rektorernas sida. I texten är direkta citat markerade med citattecken.

\section{Apelskolans ledarskap}

Det första frågeområdet handlar om huruvida lärarna upplevde att skolledningen hade formulerat visioner och mål för IKT-användningen i NGU-projektet. Lärarna framhöll att rektorerna hade stora visioner för att integrera IKT i undervisningen. De såg framför sig en framtida utveckling av en helt digital, papperslös skola. Lärarna menade att rektorerna därigenom ville förbereda eleverna för livet utanför skolan.

När det gällde lärarnas uppfattningar om rektorernas stöd och stimulans i undervisningen upplevde de att de hade fått ett betydande stöd från sina rektorer. Kommunens IKT-ansvariga anordnade dessutom regelbundet workshops där olika typer av programvaror presenterades. Rektorerna upplevdes vara villiga att hjälpa lärarna närhelst det behövdes, "Om vi ber om hjälp får vi det"; "de försöker stimulera oss" (L.A.). Rektorerna gick egna utbildningar för att lära sig mer om IKT. Lärarna såg rektorerna som sina "förebilder" när det gällde datoranvändning, "de utbildar sig hela tiden" (L.A.). Problemet, enligt lärarna, var att deras arbetstid inte räckte till för allt de uppmuntrades till och skulle ha velat göra för att utveckla sin undervisning.

Det är brist på tid när det gäller att prova olika verktyg med eleverna. Vi får använda tekniken utan att ha haft tid att utveckla de pedagogiska aspekterna. Vi har aldrig tid att gå på djupet (L.A.).

Förutom att vilja ha mer tid för IKT-utveckling, önskade lärarna att rektorerna hade varit ännu mer involverade i själva undervisningen. I början av projektet fungerade inte samarbetet så bra med de andra ländernas klasser, vilket gjorde att rektorerna även engagerade sig i undervisningen. Ett år senare gick samverkan och undervisningen bättre och rektorerna var därför inte längre lika delaktiga i själva undervisningen, "Under den senaste tiden har rektorerna varit mer frånvarande i projektets undervisning" (L.A.). Lärarna ansåg att de tilldelades för få timmar för projektet, dels för att planera arbetet tillsammans med de andra NGU-klassernas lärare, dels för det praktiska genomförandet av NGU-undervisningen. 
"Vi skulle behöva ytterligare timmar för teknisk utveckling i projektet och tid för att ladda upp elevarbeten och uppgifter på Wikispaces” (en webbplats där användare kan bidra till ett gemensamt arbete) (L.A).

Eftersom NGU-samarbetet baserades på virtuell kommunikation, var det viktigt att eleverna hade tillgång till teknisk utrustning, att datorerna fungerade och att den tekniska infrastrukturen hade tillräcklig kapacitet. Lärarna i Apelskolan svarade att de hade datorer som fungerade och att de ständigt uppmuntrades att pröva nya IKT-baserade arbetssätt. Lärarna ansåg att rektorerna visade ett stort engagemang i sitt pedagogiska ledarskap för att utveckla IKT i undervisningen. Rektorerna organiserade och ledde flera möten i veckan på skolan för att skapa ett kollektivt lärande. Lärarna berättade att de hade två typer av schemalagda möten varje vecka förutom NGU-mötena. Dels hade de pedagogisk konferens för alla lärare där pedagogiska frågor diskuterades och där lärarna visade upp olika digitala verktyg/program som de hade använt för att sprida erfarenheter till övriga kolleger. Dels organiserade de en utvecklingsgrupp där deltagandet var frivilligt från lärarnas sida. Här diskuterades olika pedagogiska frågor och idéer som kunde utveckla undervisningen på skolan. Under det första året av NGUprojektet hade rektorerna regelbundna veckomöten med de deltagande lärarna. Under det andra året av NGU hade lärarna vant sig vid det gränsöverskridande arbetet och därför hade också mötena med rektorerna blivit något färre.

\section{Pilskolans ledarskap}

I likhet med Apelskolans lärare ansåg lärarna i Pilskolan att deras rektorer var positiva till projektet, men kunde inte återge några för skolan särskilda visioner eller mål för IKT-användning. Lärarna uppgav att de kände stöd från rektorerna och de uppmuntrades att dra nytta av nya metoder och IKT-stödda program i synnerhet. "Om det kommer något nytt har vi alltid en chans att lära oss det, eller åtminstone hänvisar rektorerna till det. Så det känns som om de vill att vi ska använda oss av IKT i undervisningen" (L.P.). Utbildning inom IKT fick lärarna främst genom inspiration på studiedagar som anordnades av kommunen. Lärarna menade att rektorerna inte kunde fokusera så mycket på IKT i undervisningen då övriga rektorsuppgifter tog mycket tid. Rektorerna ansågs uppmuntra lärarna att hjälpa varandra om de provat något nytt, men i det fallet var problemet brist på tid, "vi har inte tillräckligt med tid för att samarbeta", sa lärarna. Till skillnad från Apelskolans lärare upplevde Pilskolans lärare att de hade tilldelats tillräckligt med tid för att planera och genomföra undervisningen i NGU, vilket de kände sig nöjda med. Rektorerna hade inte varit involverade i den praktiska NGU-verksamheten, även om de ansåg att rektorerna visat sig intresserade av projektet och med jämna mellanrum frågat hur det gått. En av rektorerna hjälpte ibland till att lösa tekniska problem. På frågan om hur rektors pedagogiska ledarskap såg ut, var lärarna tveksamma i sina svar, dels för att rektorerna var relativt nyanställda, dels för att de själva kände sig ansvariga för 
det pedagogiska ledarskapet, "det är framförallt vi som är ansvariga för det pedagogiska ledarskapet" (L.P.). Lärarna förväntade sig inte heller att rektorerna skulle leda dem i deras undervisning. Istället föredrog de att planera kurserna utifrån den nationella läroplanen och själva avgöra hur de ville utforma undervisningen,

... vi vill inte att rektorerna lägger sig i undervisningen. Vi vill inte bli styrda. Det är moment 22; Å ena sidan skulle vi vilja ha lite vägledning, å andra sidan tillåter vi inte att någon kommenterar hur vi väljer att bedriva vår undervisning (L.P.).

Till skillnad från Apelskolans lärare uppgav lärarna på Pilskolan att de hade haft stora tekniska problem. Lärarna på Pilskolan svarade:

Hälften av pekplattorna har varit dåliga. På grund av detta har lektioner fått planeras om. Det gick så långt att eleverna inte tyckte att det var värt att ta med sina datorer till skolan. Vi har alltid varit tvungna att planera för en kombination av papper, pennor och datorer.

Lärarna på Pilskolan uppgav att de hade tre typer av möten, "arbetsplatsmöten, ämnesmöten och gruppmöten". Arbetsplatsmötena leddes av rektorerna medan lärarna ledde de andra mötena. Lärarna menade att eftersom rektorerna inte deltog i de pedagogiska mötena var det lärarna som var ansvariga för de pedagogiska frågorna. Det förekom heller inga planerade möten specifikt för NGU. De två NGU-lärarna på skolan hade sinsemellan möten om så behövdes. Rektorerna informerades om projektet då och då när de träffades på andra möten eller spontant under skoldagen. Även om rektorerna inte deltog i de pedagogiska mötena visade de ett intresse för utbildningsfrågor. Som ett exempel tog rektorerna upp sådana frågor vid medarbetarsamtalen.

\section{Diskussion}

Rektors roll som pedagogisk ledare har fătt en allt viktigare betydelse för skoloch IKT-utveckling sedan införandet av det mål- och resultatstyrda systemet. I föreliggande fallstudier har rektors pedagogiska ledarskap undersökts utifrån ett lärarperspektiv inom ramen för skolutvecklingsprojektet NGU. Lärarna från de två skolorna beskriver varsina typer av ledarskap, där Apelskolans rektorer upplevs arbeta nära lärarna och undervisningen, och där de försöker stödja lärarna och möta deras behov av kompetens och teknik. Pilskolans rektorer beskrivs snarare $\mathrm{i}$ termer av en traditionell rektorsroll, där ansvaret för undervisningen överlämnats till lärarna och där rektorerna heller inte förväntades delta. Med utgångspunkt från de två frågeställningarna i studien diskuteras resultatet dels utifrån faktorer i ledarskapet som ansetts viktiga för stöd i skolans IKT-utveckling. Dels diskuteras vad som karaktäriserar ett IKT- 
främjande ledarskap, där det distribuerade ledarskapet lyfts fram, som kontrast till det traditionella sättet att se på rektors och lärares skilda yrkesroller.

\section{Kritiska faktorer i rektors ledarskap för att skapa IKT-utveckling}

Lärarna på både Apelskolan och Pilskolan ansåg att deras verksamheter bedrevs på ett målinriktat sätt, dels när det gällde ökad IKT-användning, dels när det gällde att uppfylla de nationella målen. Skillnaden var att Apelskolan hade formulerat en egen vision för IKT-användning, som lärarna kunde återge vid intervjun. Enligt Ertmar \& Ottenbreit-Leftwich (2010) skapar en vision bilder och förväntningar om vad IKT-användning ska leda till och det påverkar lärarnas tänkande kring IKT samt deras motivation och vilja att använda tekniken. Detta ligger också i linje med läroplanen, där skolor uppmuntras att formulera egna pedagogiska visioner och mål i förhållande till de nationella målen (Skolverket, 2011). I Pilskolan kan avsaknaden av en tydlig vision för IKT i samband med NGU möjligen till viss del förklaras av att båda rektorerna var relativt sett nya på sina tjänster och ej varit ansvariga för projektet när det startade.

I både Apelskolan och Pilskolan ansåg lärarna att rektorerna var angelägna om att öka IKT-användning i undervisningen. Detta kräver en organisation där tid avsätts för att kunna utveckla den nödvändiga pedagogiska och tekniska kompetensen. Schibeci m. fl., (2008) framhåller tiden som en kritisk faktor för att åstadkomma utveckling och förändring. Detta bekräftar Apelskolans lärare som var nöjda med alla lärtillfällen om IKT, men saknade tid för att testa och praktisera det de lärt sig. Inte heller upplevde de att arbetstiden räckte till för alla uppgifter i NGU-projektet. Däremot upplevde lärarna i Pilskolan att de tilldelats tillräckligt med tid i projektet. Det de saknade var pedagogiska möten om IKTanvändning, för att utbyta idéer och få mer kunskaper. Följaktligen kan man dra slutsatsen att organisering av regelbundna möten, men också att lärarna tilldelas tillräckligt med tid är kritiska faktorer för att lärarna ska öka sin IKT-kompetens och använda den i undervisningen. En annan avgörande faktor är teknisk support och en fungerande infrastruktur (Ottestad, 2013; Law, 2008). Lärarna på Pilskolan uttryckte i intervjun att icke fungerande datorer inte bara skapat missnöje och frustration bland lärare och elever. En ytterligare konsekvens var att datorerna lämnades oanvända och lärarna måste ta mer tid i anspråk för att planera och genomföra lektioner med hjälp av flera arbetssätt. Brister i den tekniska utrustningen på Pilskolan vittnar om att samtliga tre delar (ämneskunskaper, pedagogik och teknik) måste fungera för att IKT ska utvecklas i undervisningen (Harris, m. fl., 2009). Att klassamarbetet i Pilskolan trots allt fungerade beror sannolikt på lärarnas idoga insatser men också på att forskarna i projektet var till stöd.

Ett skolprojekt utan personligt stöd eller engagemang från rektor har lägre chans att lyckas (Stedøy, 2006; Petersen, 2010, 2012, 2013). Därför är det viktigt att lärarna känner sig sedda och uppskattade av sin skolledning, men 
också att lärare och skolledare tillsammans upprättar tydliga mål för projektet för att klargöra vilka förväntningar man har på varandra, och vilket resultat man förväntas uppnå. I båda skolorna kände sig lärarna bekräftade och uppmuntrade av sina respektive rektorer. Även om Pilskolans lärare inte såg sina rektorer som pedagogiska ledare vittnade de om en positiv relation och stöd från sina rektorer.

Det pedagogiska och sociala klimatet, skolkulturen, ger en komplex bild av värderingar och normer som utvecklas över tid (Berg, 2011). Skilda skolkulturer kan möjligen vara en förklaring till skillnader i fråga om upplevt ledarskap mellan Apelskolan och Pilskolan. Apelskolan låg till skillnad från Pilskolan i ett multietniskt område, där de flesta av eleverna hade ett annat modersmål än svenska och i genomsnitt presterade de förhållandevis lågt på de nationella proven. Mot den bakgrunden stod rektorerna i de två skolorna inför olika utmaningar och var tvungna att prioritera olika utbildningsfrågor. På Apelskolan var förmodligen undervisningsmetoder och ämnesdidaktik högt prioriterade områden för rektorerna i syfte att stödja lärarna i deras ansträngningar att höja elevernas prestationsnivåer. Följaktligen kan man anta att rektorerna i Apelskolan var mer vana vid ett kollektivt ledarskap. Det upplevdes som naturligt att ta hjälp av rektor i undervisningen. I Pilskolan stod rektorerna sannolikt inför andra problem, gissningsvis inte så nära kopplade till undervisning. Lärarna skötte undervisningen och de ville heller inte ha någon inblandning från rektorerna. Därmed verkade det mer distanserade ledarskapet upplevas normalt för både rektorer och lärare. En annan skillnad som kan ha spelat roll handlar om att lärarna i de två skolorna undervisade elever på olika stadier och de hade olika utbildningsbakgrund. Ämneslärare för högre årskurser och 1-7 lärare för lägre kan möjligen ha utvecklat olika kulturella synsätt som inneburit olika förväntningar på ledarskapet.

\section{Distribuerat ledarskap kontra leda utifrån formella roller}

Dexter (2008) framhåller ett IKT-ledarskap där rektor kontinuerligt arbetar tillsammans med lärare och IKT-samordnare för att utveckla undervisningsmetoder, förbättra kursdesign och för att öka elevernas delaktighet och motivation. Det kollektiva ledarskapet bygger på att var och en utifrån sin kompetens bidrar till IKT-utveckling, ett så kallat distribuerat ledarskap. Till skillnad från ett traditionellt ledarskap som följer en hierarkisk struktur som bygger på formella roller, ligger betoningen på att uppmuntra till samarbete och till utbyte av kunskaper och erfarenheter. I förgrunden står problemlösning och gemensam utveckling av skolans IKT-användning. I intervjuerna med lärarna i båda skolorna har två typer av ledarskap kunnat urskiljas. Ledarskapet i Apelskolan kan i vissa avseenden liknas vid ett distribuerat ledarskap. Rektorerna var själva engagerade i den pedagogiska verksamheten, de ansvarade för skolans pedagogiska veckomöten där IKT-utveckling stod i centrum, de deltog i NGU-möten och de var även involverade i NGU-undervisningen när så behövdes. Att rektor driver och organiserar det pedagogiska arbetet är en viktig 
förutsättning för skolutveckling (Leithwood m. fl., 2008). Lärarna menade att rektorerna inte bara var intresserade av IKT i undervisningen, de utbildade sig också själva inom IKT för att sedan föra kunskaperna vidare. Utvecklingsgruppen på skolan var också ett exempel på forum där rektorer och lärare möttes och utbytte erfarenheter. Följaktligen samverkade de med pedagogerna och uppmuntrade till IKT-utveckling genom att personligen engagera sig på olika vis. I ett distribuerat ledarskap är överföring av kompetens ömsesidig, där rektorer, lärare och IT-samordnare lär av varandra. En samverkan som innebär att personer med olika yrkeserfarenheter och olika kunskaper hjälper varandra att lösa problem och utveckla skolans verksamhet utan ett underliggande ramverk för strikt kontroll (Bennett, 2008; Harris m. fl., 2007; Leithwood m.fl., 2008). I ett IKT-perspektiv är dessa faktorer möjligen ännu viktigare på grund av att det krävs speciella kunskaper och fungerande digitala resurser, vilka också ständigt behöver förnyas i takt med den utveckling som sker på området. Alla aktörer på skolan blir därmed beroende av varandras kunskaper, erfarenheter och förmågor att utveckla den digitala kompetensen. För att stödja en sådan utveckling framstår en teambaserad organisation som viktig (Larsson, 2004; Spillane, 2005; Dexter, 2008; Leithwood m.fl., 2008; Erstad, 2011; Larsson \& Löwstedt, 2014).

Lärarna i Pilskolan beskrev rektorernas ledarskap som mer distanserat från själva undervisningen än i Apelskolan. Rektorerna uppgavs vara angelägna om att göra det möjligt för lärarna att utveckla sina färdigheter inom IKT och uppmuntrade lärarna i NGU-projektet, men inte genom att personligen delta i undervisning med stöd av digitala verktyg. Till skillnad från Apelskolan tilldelade rektorerna i Pilskolan å ena sidan en förhållandevis generös mängd tid till lärarna för att genomföra projektet. $\AA$ andra sidan uppgavs rektorerna inte ha deltagit i möten, i diskussioner eller i planering av den gränsöverskridande undervisningen. Detta var en naturlig följd av att lärarna på skolan inte efterfrågade inblandning av rektor i frågor som rörde undervisningen. $\AA$ ena sidan ville lärarna inte bli styrda, men å andra sidan ville de ha stöd från rektorerna när det passade dem. Lärarna verkade vara rädda för att förlora sin självständighet i yrkesrollen. Följaktligen kan man konstatera att både lärare och rektorer agerade utifrån sina respektive traditionsenliga roller. Det empiriska exemplet påminner om vad Berg (2011) kallar det osynliga kontraktet, där lärarna ser undervisning och pedagogisk utveckling som sitt område och rektor ansvarar för de administrativa uppgifterna. Ur ett skolutvecklingsperspektiv definierar Björkman (2011) två typer av ledarskap, ett framgångsrikt eller "ett deltagande ledarskap" som kan liknas vid ett distribuerat ledarskap, och ett mindre framgångsrikt eller "ett separerande ledarskap". Ledarskapet i Pilskolan visar likheter med ett separerande ledarskap. Följaktligen borde Apelskolan ha större potential för skolutveckling när det gäller IKT-användning i undervisningen än Pilskolan.

\section{Avslutning - distribuerat ledarskap för IKT-utveckling}


Effektivt ledarskap är en viktig förutsättning för integrering och implementering av IKT i undervisningen. Vad undervisande lärare ser som viktigt i ledarskapet för en sådan utveckling är därför av betydelse. Syftet i studien var att undersöka hur lärare upplevde sina rektorer som pedagogiskt stöd i IKT-baserad undervisning i samband med det nordiska skolutvecklingsprojekt NGU. Dexter (2008) lyfter fram tre grundläggande funktioner som anses främja ett pedagogiskt IKT-ledarskap: att formulera mål och visioner för IKT-användning, att stödja och tillgodose med kompetensutveckling för lärarna samt att organisera och tillhandahålla nödvändiga resurser. Dessa funktioner kräver samarbete mellan olika yrkesroller på skolan, och enligt Ertmer \& OtterbreitLeftwich (2010) gemensamma pedagogiska uppfattningar om att IKT kan göra undervisningen effektivare. Organisering av undervisning bör därför ses som en kollektiv uppgift, där rektor samverkar med lärare och IKT-samordnare och där de organiserar för ett kontinuerligt samarbete för att utveckla digital kompetens. I artikeln har lärare intervjuats från två skolor som deltagit i NGU-projektet, och ur resultatet har två typer av ledarskap kunnat urskiljas. En typ har likheter med ett distribuerat ledarskap (Spillane, 2005; Dexter, 2008;), där skolan hade en tydlig målsättning för IKT-användning i undervisningen. Vidare arbetade rektorer, lärare och IKT-ansvariga tillsammans i team där de kontinuerligt hade gemensamma möten om projektet, om IKT-användning i undervisningen och skolutveckling i övrigt. Rektorerna utbildade sig själva inom IKT för att kunna diskutera och stimulera lärarna och för att stödja dem i NGU-projektet. Genom teamet och närheten till undervisningen informerades rektorerna om problem som uppstod och vilka behov som behövde tillgodoses. Den andra typen av ledarskap beskrevs som mer formell till sin karaktär och mer distanserad från IKT-användning i undervisningen. Några för skolan särskilda mål eller visioner för IKT-användning var inte kända för lärarna. Däremot upplevde de att rektorerna ansåg det viktigt att utveckla digital användning i undervisningen, men överlämnade ansvaret för IKT-kompetens till studiedagar och till lärarnas egna initiativ. Lärarna på denna skola uttryckte att de heller inte ville bli styrda av någon rektor, då de såg undervisningen som en uppgift för lärarna, en uppfattning som ligger i linje med en mer traditionell skolkultur. Följaktligen visade lärarna ett motstånd mot att samarbeta med sina rektorer inom ramen för sin undervisning. Dock framhöll lärarna att de hade bra kontakt med sina rektorer, de uppgavs stödja dem i NGU genom att ge dem tillräckligt med tid för planering och genomförande av projektet och uppmuntran i deras arbete.

Föreliggande studie har visat exempel på hur lärare från två skolor har upplevt sina respektive rektorers IKT-ledarskap i ett skolutvecklingsprojekt, och därmed är studien ett bidrag till diskussionen om ledarskapets betydelse för skolutveckling. Mot bakgrund av införandet av IKT i undervisningen har behov vuxit hos såväl lärare som rektorer att utveckla sin pedagogiska och tekniska kompetens men också hur en sådan utveckling kan organiseras. 
Att arbeta i projekt som exempelvis NGU ger en möjlighet att pröva nya former för samarbete och ledarskap. Klassamarbetena var beroende av stöd och engagemang från rektors sida för att tillgodose med resurser, tid, teknik och kompetens. Projektet var inte avgränsat till klassrummet eller till den enskilda skolan. Den gränsöverskridande undervisningen gjorde det beroende av samverkande klasser och skolor. Skolans beslut kring ekonomiska, pedagogiska och tekniska frågor måste ses utifrån de behov och synpunkter från lärare och skolor som var involverade i projektet. Rektor hade dessutom ett gemensamt ansvar tillsammans med andra medverkande skolors rektorer att genomföra projektet på ett framgångsrikt sätt. Mot den bakgrunden blev det ännu viktigare för rektorerna att engagera sig i den pedagogiska verksamheten.

Skolprojekt där endast ett fåtal klasser och lärare är inblandade, vilket gällde båda skolorna i föreliggande studie, riskerar att skapa "öar" och därmed misslyckas med att bidra till spridning av erfarenheter och därmed utveckling för resten av skolan (Grensjö, 2002). Dock ser vi i studien hur lärare som upplevt ett distribuerat ledarskap ansåg att det bidragit till att utveckla IKT på skolan som helhet. Ett skolledarskap där rektor är organisatör, inspiratör och deltar i olika skolaktiviteter borde därmed bidra till att minska risken för att utveckla "öar".

\section{Referenser}

Bennett, N. (2008). Distributed Leadership and IT. I J. Voogt \& G. Knezek (Red.), International Handbook of Information Technology in Primary and Secondary Education. (s. 597-614). New York: Springer.

Berg, G. (2011). Skolledarskap och skolans frirum. Lund: Studentlitteratur.

Björkman, C. (2011). Skolans ledarskap som intern förbättringskapacitet. I J. Höög \& O. Johansson (Red.), Struktur, kultur och ledarskap. (s.135-152). Lund: Studentlitteratur.

Bryderup, I. M. \& Kowalski, K. (2002). The role of the local authories in the integration of ICT in learning. Journal of Computerassisted Learning, 18, 470-479. doi: 10.1046/j.0266-4909.2002.00258.x

Denscomb, M. (2009). Forskningshandboken för småskaliga projekt inom samhällsvetenskaperna. Lund: Studentlitteratur.

Dexter, S. (2008). Leadership for IT in Schools. I J. Voogt \& G. Knezek (Red.), International Handbook of Information Technology in Primary and Secondary Education. (s. 541-554). New York: Springer.

Dysthe, O. (2001). Dialog, samspel och lärande. Lund: Studentlitteratur.

Eisenhardt, K.M. (1989). Building theories from case study research. Academy Management Review, 14(4), 532-550. http://search.proquest.com.ezproxy.server.hv.se/docview/210938650

Ekholm, M., Blossing, U., Kåräng, G., Lindvall, K. \& Scherp, H-Å. (2000). Forskning om rektor - en forskningsöversikt. Stockholm: Skolverket.

Erstad, O. (2011). Digitalt kompetanse i skoler. I O. Erstad \& T. E. Hauge (Red.), Skoleutvikling og digitalemedier: Kompleksitet, mangfold, ekspansiv läring. (s. 47-63). Oslo: Gyldendal Akademisk.

Ertmer, P. \& Ottenbreit-Leftwich, A. (2010). Teacher technology change: How knowledge, confidence, beliefs, and culture intersect. Journal of Research on Technology in Education, 42(3), 255-284. doi: 10.1080/15391523.2010.10782551 
Fejes, A. \& Thornberg, R. (2009). Handbok i kvalitativ analys. Stockholm: Liber.

Friedman, V. (2001). Action Science: Creating Communities of Inquiry in Communities of Practice. I P. Reason \& H. Bradbury (Red.), Handbook of Action Research. (s.159-170). London: Sage Publication.

Fullan, M. (2007). The new meaning of educational change (4:e uppl.). New York: Teachers College Press.

Grensjö, B. (2002). Erfarenheter sprids - Kunskaper används? Enkätstudie bland KK-stödda mindre skolutvecklingsprojekt. Pedagogiska rapporter, $\mathrm{Nr}$ 67. Umeå Universitet: Pedagogiska institutionen.

Hallerström, H. (2006). Rektors normer i ledarskapet för skolutveckling. Lunds universitet: Sociologiska institutionen.

Hallin, A. \& Karrbom Gustafsson, T. (2012). Projektledning. Malmö: Liber.

Hallinger, \& Heck, (2010). Leadership for Learning: Does Collaborative Leadership Make a Difference in School Improvement? Educational Management Administration Leadership, 38(6), 654-678. doi: 10.1177/1741143210379060

Harris, A., Leithwood, K., Day, C., Sammons, P. \& Hopkins, D. (2007). Distributed leadership and organizational change: Reviewing the evidence. Journal of Educational Change, 8(4), 337-347. doi: 10.1007/s10833-007-9048-4

Harris, J., Mishra, P. \& Koehler, M. (2009). Teachers’ Technological Pedagogical Content Knowledge and Learning Activity Types: Curriculum-based Technology Integration Reframed. Journal of Research on Technology in Education, 41(4), 393-416. doi: 10.1080/15391523.2009.10782536

Hundeide, K. (2003). Sociokulturella ramar för barns utveckling - barns livsvärldar. Lund: Studentlitteratur.

Hylén, J. (2013). Digitalisering av skolan - en kunskapsöversikt. Ifous Rapportserie 2013:1, Stockholm. http://docplayer.se/12043471-Digitalisering-i-skolan-en-kunskapsoversikt-janhylen.html

Höög, J. \& Johansson, O. (2011). Struktur, kultur, ledarskap - ett projekt och dess resultat. I J. Höög \& O. Johansson (Red.), Struktur, kultur och ledarskap. (s. 13-22). Lund: Studentlitteratur.

Kvale, S. (2008). Den kvalitativa forskningsintervjun. Lund: Studentlitteratur.

Lantz-Andersson, A. \& Säljö, R. (2014). Lärmiljöer i omvandling - En yrkesroll i utveckling. I A. Lantz-Andersson \& R. Säljö (Red.). Lärare i den uppkopplade skolan. (s. 13-36). Malmö: Gleerups.

Larsson, P. (2004). Förändringens villkor. En studie om organisatoriskt lärande och förändring inom skolan (Doktorsavhandling). Handelshögskolan i Stockholm

Larsson, P. \& Löwstedt, J. (2014). Strategier och Förändringsmyter, ett organisationsperspektiv på skolutveckling och lärares arbete (2:a uppl.). Lund: Studentlitteratur.

Law, N. (2008). In search of explanations. I N. Law, W.J. Pelgrum \& T. Plomp (Red.), Pedagogy and ICT use in schools around the world: findings from IEA SITES 2006 study. (s. 251-262). Dordrecht: Springer.

Leithwood, K., Day, C., Sammons, P., Harris, A. \& Hopkins, D. (2006). Successful School Leadership. What It Is and How It Influences Pupil Learning. National College for School Leadership. Research Report RR 800. University of Nottingham. ISBN9781844788224.

Leithwood, K. Mascall, B., Strauss, T., Sacks, R., Memon, N. \& Yashkina, A. (2007). Distributed Leadership to Make Schools Smarter: Taking the Ego Out of the System. Leadership and Policy in Schools, 6(1), 37-67. doi: 10.1080/15700760601091267 
Leithwood, K., Harris, A. \& Hopkins, D. (2008). Seven strong claims about successful school leadership. School Leadership \& Management, 28(1) 27-42. doi: 10.1080/13632430701800060

Lundgren, U.P. (2014). Teknik för pedagogik och pedagogik som teknik: Såsom i en spegel. I A. Lantz-Andersson \& R. Säljö (Red.), Lärare i den uppkopplade skolan. (s. 231-254). Malmö: Gleerups.

Ottestad, G. (2013). School leadership for ICT and Teacher's Use of Digital Tools. Nordic Journal of Digital Literacy, 8 (01-02), 107-125. https://www.idunn.no/dk/2013/0102/school_leadership_for_ict_and_teachers_use_of_digital_tools

Owstone, R. (2003). School context, sustainability and transferability of innovation. I R. B. Kozma (Red.), Technology, innovation and educational change: A global perspective. (s. 125-161). Eugene, Oregon: ISTE publications.

Petersen, A-L. (2010). Pedagogiskt ledarskap i matematikundervisning. I S. Lagrosen, U. Lundh Snis \& E. Nehls (Red.), Lärande i och för det nya arbetslivet. (s. 103-123). Lund: Studentlitteratur.

Petersen, A-L. (2012). Matematik behöver också en berättelse, om pedagogiskt ledarskap med fokus på elevens motivation. Acta Didactica Norge - Internasjonalt tidsskrift för fagdidaktisk forsknings- og utviklingsarbeid, 6(1), art.10. ISSN 1504-9922

Petersen, A-L. (2013). Utvärdering av matematikprojekt i en kommuns fyra högstadieskolor år 2012. Högskolan Västs rapportserie 2013:1. Trollhättan.

Petersen, A-L \& Bunting, L. (2012). Pedagogical use of laptops in one-to-one environment in a Swedish primary school. I Contemporary Educational Technology, 3(4), 249-264. http://www.cedtech.net/articles/34/341.pdf

Schibeci, R., MacCallum, J., Cumming-Potvin, W., Durrant, C., Kissane, B. \& Miller, E-J. (2008). Teachers' journeys towards critical use of ICT. Learning, Media and Technology. 33(4), 313-327. doi: 10.1080/17439880802497065

Silverman, D. (2006). Interpreting Qualitative Data (3:e uppl.). London: Sage.

Skolinspektionen. (2012a.). Rektors ledarskap, med ansvar för den pedagogiska verksamheten. Kvalitetsgranskning, Rapport 2012:1. http://www.skolinspektionen.se/Documents/Kvalitetsgranskning/rektor2/slutrapportrektors-ledarskap-2012.pdf

Skolinspektionen (2012b.). Satsningarna på IT används inte i skolornas undervisning. Dnr. 40-2011:2928. https://www.skolinspektionen.se/globalassets/publikationssok/granskningsrapporter/kvalitetsgran skningar/2012/it/pm-it-iundervisningen.pdf

Skolinspektionen. (2014). Från huvudmannen till klassrummet - tät styrkedja viktig för förbättrade kunskapsresultat. Dnr 2014:6739.

http://www.skolinspektionen.se/Documents/publikationssok/regeringsrapporter/arsrapport er/arsrapport-2014.pdf

Skolverket. (2011). Läroplan för grundskolan, förskoleklassen och fritidshemmet 2011.

Stockholm: Skolverket.

Skolverket. (2013). SIRIS Database. http://siris.skolverket.se/siris/f?p=Siris:1:0

Spillane, J. (2005). Distributed Leadership. The Educational Forum, 69(2), 143-150. doi: $10.1080 / 00131720508984678$

Stedøy, I. M. (2006). Hur blir man en duktig matematiklärare? I J. Boesen, G. Emanuelsson, R. Ryding, A. Wallby \& K. Wallby (Red.), Lära och undervisa matematik internationella perspektiv. (s. 241-257). Göteborg: Nationellt Centrum för Matematikutbildning.

Säljö, R. (2015). Lärande - En introduktion till perspektiv och metaforer. Malmö: Gleerups. 
Tallvid, M. (2015). 1:1 i klassrummet - analyser av en pedagogisk praktik i förändring (Doktorsavhandling). Göteborgs Universitet.

Voogt, J. (2008). IT and Curriculum Processes: Dilemmas and Challenges. I J. Voogt \& G. Knezek (Red.), International Handbook of Information Technology in Primary and Secondary Education. (s. 115-132). New York: Springer. 